\title{
Ana Dil Olarak Japonca Eğitimine Genel Bir Bakış: \\ İlkokul Japonca Dersi Öğretim Programı ve İlkokul 1. Sınıf Japonca Ders Kitabı İncelemesi
}

$$
\text { Gonca Varoğlu }
$$

Doğu Dilleri ve Edebiyatları Bölümü, Fen Edebiyat Fakültesi, Nevşehir Hacı Bektaş Veli Üniversitesi, Nevşehir, Türkiye

Sorumlu Yazar: Gonca Varoğlu, goncavaroglu@nevsehir.edu.tr

Makale Türü: Derleme Makalesi

Kaynak Gösterimi: Varoğlu, G. (2021). Ana dil olarak Japonca eğitimine genel bir bakış: İlkokul Japonca Dersi Öğretim Programı ve İlkokul 1. Sınıf Japonca Ders Kitabı incelemesi.Eğitimde Kuram ve Uygulama,17(Özel Sayı 1), 60-73. doi: 10.17244/eku.878369

Etik Not: Araştırma ve yayın etiğine uyulmuştur. Bu çalışma, "Derleme Makalesi" olup ayrıca bir etik onay süreci işletilmemiştir.

A General Outlook of Japanese Education as a Mother Tongue: The Examination of the Elementary School Japanese Curriculum Guidelines and Elementary School 1st Grade Japanese Textbook

\section{Gonca Varoğlu}

Department of Eastern Languages and Literature, Faculty of Science and Literature, Nevsehir Haci Bektas Veli University, Nevsehir, Turkey

Corresponding Author: Gonca Varoğlu, goncavaroglu@nevsehir.edu.tr

Article Type: Review Article

To Cite This Article: Varoğlu, G. (2021). Ana dil olarak Japonca eğitimine genel bir bakış:İlkokul Japonca Dersi Öğretim Programı ve İlkokul 1. Sınıf Japonca Ders Kitabı incelemesi. Eğitimde Kuram ve Uygulama, 17(Special Issue 1), 60-73. doi: 10.17244/eku.878369

Ethical Note: Research and publication ethics were followed. This study is "Review Article"; hence, no proceed an ethical clearance evaluation. 


\title{
Ana Dil Olarak Japonca Eğitimine Genel Bir Bakış: İlkokul Japonca Dersi Öğretim Programı ve İlkokul 1. Sınıf Japonca Ders Kitabı İncelemesi
}

\author{
Gonca Varoğlu
}

Doğu Dilleri ve Edebiyatları Bölümü, Fen Edebiyat Fakültesi, Nevşehir Hacı Bektaş Veli Üniversitesi, Nevşehir, Türkiye

ORCID:https://orcid.org/0000-0002-0512-9327

\begin{tabular}{|c|c|}
\hline Öz & Makale Bilgisi \\
\hline 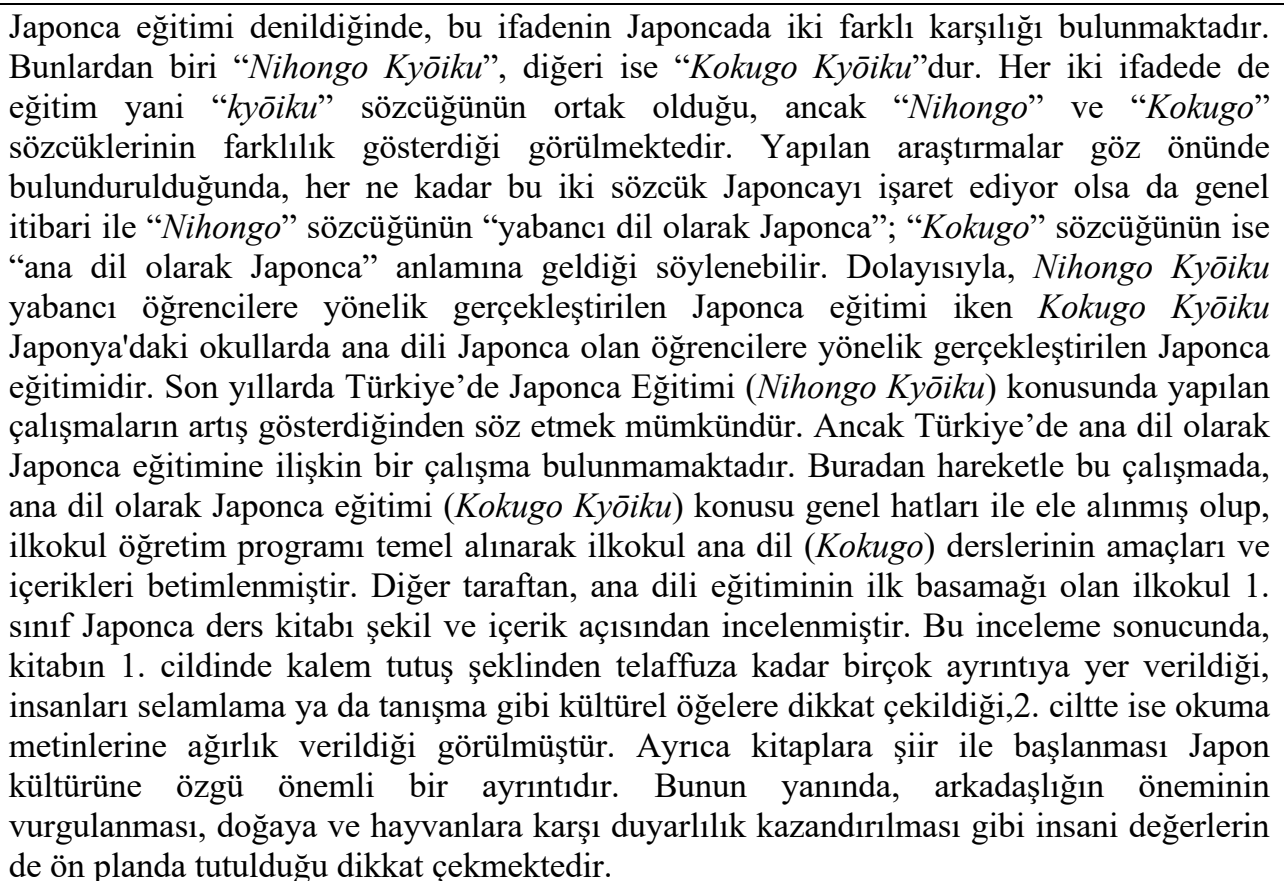 & 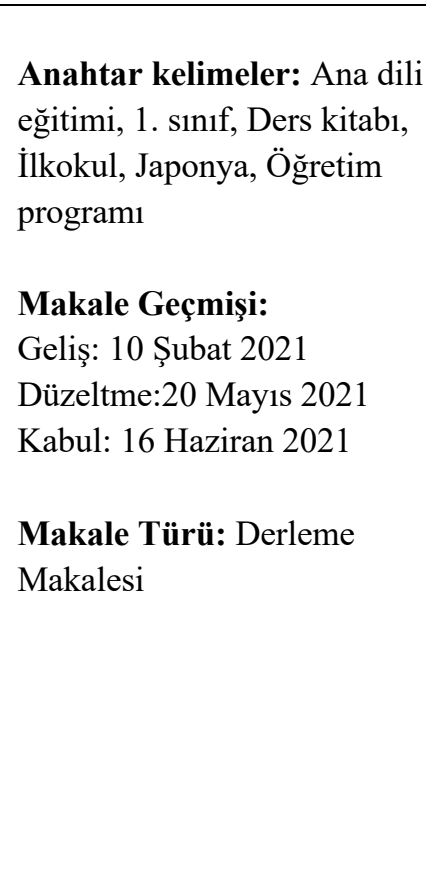 \\
\hline
\end{tabular}




\section{A General Outlook of Japanese Education as a Mother Tongue: The Examination of the Elementary School Japanese Curriculum Guidelines and Elementary School 1st Grade Japanese Textbook}

\begin{tabular}{|c|c|}
\hline Abstract & Article Info \\
\hline $\begin{array}{l}\text { When it comes to Japanese education, this expression has two different translations in } \\
\text { Japanese. One of them is "Nihongo Kyoiku" and the other is "Kokugo Kyōiku". In both } \\
\text { expressions, it is seen that the word "kyōiku" is the same, but the words "Nihongo" and } \\
\text { "Kokugo" are different. Considering the researches, although these two words refer to } \\
\text { Japanese, generally the word "Nihongo" means "Japanese as a foreign language"; and } \\
\text { "Kokugo" means "Japanese as the mother tongue". Hence, Nihongo Kyoiku is Japanese } \\
\text { education for foreign students, while Kokugo Kyoiku is Japanese education for native } \\
\text { Japanese students in schools in Japan.In recent years in Turkey, it can be said that the } \\
\text { studies on Japanese Education (Nihongo Kyoiku) have increased. But in Turkey, there is } \\
\text { no study on Japanese education as a mother tongue. Based on this, in this study, the } \\
\text { subject of Japanese education as a mother tongue (Kokugo Kygoiku) is discussed in } \\
\text { general terms and the aims and contents of elementary school mother tongue (Kokugo) } \\
\text { courses are described based on the elementary school curriculum guidelines. On the other } \\
\text { hand, elementary school 1st grade Japanese textbook, which is the first step of mother } \\
\text { tongue education, was analyzed in terms of form and content. As a result of this analysis, } \\
\text { it has been seen that in the first volume of the book, many details are included from the } \\
\text { way of holding the pencil to the pronunciation, it is seen that cultural elements such as } \\
\text { greeting people or meeting people are emphasized, and there were many reading texts in } \\
\text { the second volume. Moreover, starting books with poetry is an important detail unique to } \\
\text { Japanese culture. Besides, human values such as emphasizing the importance of friendship } \\
\text { and providing sensitivity to nature and animals are also prioritized in the textbook. }\end{array}$ & $\begin{array}{l}\text { Article History: } \\
\text { Received: } 10 \text { February } 2021 \\
\text { Revised: } 20 \text { May } 2021 \\
\text { Accepted: } 16 \text { June } 2021\end{array}$ \\
\hline
\end{tabular}




\section{Extended Summary}

The word Kokugo, which means "national language of Japan", became more common and widely known with the introduction of this course to the education system in the Meiji period (1968-1912). The subject of mother tongue education has gained importance with the proposition of "the necessity of a standard language to establish a modern nation" in Japan. Although Japanese language education was first introduced in the 1920s, it was not scientifically evaluated until 1930.The issue of creating new courses was brought to the agenda in the elementary and secondary school regulations in 1886 but the addition of the Japanese language courses to the elementary schools was first made in 1900 with the revision of the elementary school regulations. A common Japanese textbook for elementary schools in Japan was published in 1903. When we look at the current Japanese education system, Japanese courses are available in elementary, secondary, and high schools.

The aim of this study is to deal with the subject of Japanese Education (Jpn: Kokugo Kyōiku) in general terms, to describe the aims and contents of the elementary school Japanese courses on the basis of the elementary school curriculum guidelines on the official website of the Ministry of Education, Culture, Sports, Science and Technology of Japan, and, in this respect, to analyze a randomly selected 1st grade Japanese textbook in terms of its form and content.

According to the elementary school curriculum guidelines published in 2017, the aim of the Japanese course is to improve the qualifications and skills of understanding and expressing Japanese correctly. In the 1st and 2nd grades, the students are predominantly expected to speak by putting the events into an order and gain the skill of writing a paragraph by following a sequence. In addition, it is emphasized that fun should be added to the reading practices to facilitate the acquisition of reading habits in the first two years. The purpose of developing imagination is another important topic in the 1st and 2nd grades.

On the other hand, it is seen that the content of Japanese courses for each grade is described in detail in the curriculum guidelines. In 1st and 2nd grade Japanese courses, the content of the courses consists of encouraging students to speak on a specific subject, speaking using formal and informal forms, paying attention to pronunciation and intonation, asking questions, answering, greeting people, writing coherent sentences and paragraphs, reading aloud and understanding what they read.

The elementary school 1st grade Japanese textbook, discussed in this study, was published by Mitsumura Tosho publishing house in 2012. This textbook consists of 2 volumes. It is $25 \times 17.5 \mathrm{~cm}$ in size and has a luxurious colorful cardboard cover. The first volume of textbook consists of 124 pages and the second volume consists of 132 pages. The pages are cast-coated paper. When the textbook is analyzed in general, it is seen that there are many pictures in the book, the writings are large and legible, and there is a gradual progression from words to sentences, from sentences to texts. In addition, when 2 volumes of the textbook are evaluated in terms of their size, it is seen that the books have a normal size. It is thought that this makes the books useful both in terms of carrying and usage.

There is no writing in the pictures on the first pages of the textbook. All of these pictures follow one another as if relating the progression of a story. In these pictures, it is possible to say that the students are taught the values of love of school and friendship. Then comes the subject of teaching greetings, which is the most basic element of social life and the first step of communication.

After the greetings, the subject of getting to know each other comes. Introducing yourself and getting to know each other is as important as greeting, which is considered the beginning of communication. Especially in Japanese, there are certain expressions used during the meeting. Using these expressions correctly is of great importance for the start and continuation of communication.

After the expressions of greeting and meeting, the writing system study begins. While studying the spelling and pronunciation of syllables, it is seen that new words related to newly learned syllables are introduced. On the other hand, it is possible to say that the meanings of new words are supported by pictures. In addition, short texts are also included, apart from words and sentences.

When the Japanese textbook is evaluated in terms of texts, it is seen that there are longer texts towards the end of the first volume, and sometimes folk tales are included in the second volume. Compared to the first volume, in the second volume, the pictures have been observed to decrease in number and the writings increase. On the other hand, there are occasional games and puzzles in both volumes.

As a result of this study, it is understood that the 1st grade Japanese textbook includes many details including the way of holding the pencil to the pronunciation, in addition to general information such as the diction and the meanings of the words. Besides, it is seen that cultural elements such as greeting people or meeting people also appear. Moreover, starting the books with poetry is an important detail unique to Japanese culture. On the other hand, the inclusion of human values such as the importance of friendship and teaching sensitivity to nature and animals are also prioritized in the textbook. 


\section{Giriş}

Ait olduğu toplumun tarihi, kültürü, inanışları, gelenek ve görenekleri başta olmak üzere o topluma ait her şeyi bünyesinde barındıran dil, milleti bir arada tutan en önemli unsurlardan biridir. Burada sözü edilen dil, elbette bireylerin çevresiyle ve toplumla bağını oluşturan ana dilidir. Ana dili, toplumun birlik ve beraberliği açısından oldukça önemli bir yere sahip olup, toplumun millet olarak devamını sağlamaktadır. Sinan (2006), çağdaş ülkelerin ana dilin ulusal bilinç ve duyarlılığın oluşmasındaki büyük rolü nedeniyle ana dili eğitim ve öğretimine büyük özen gösterdiğini belirtmektedir. Ana dili eğitimi, bireylerde milli kimlik bilincinin oluşturulması açısından büyük öneme sahiptir. Ishihara (2005), ana dili eğitiminin, bireyi toplumun beklediği ideal kişiliğe ulaştıran ahlaki bir eğitim olduğunu dile getirmektedir.

Bu çalışmanın konusu, Japonya'daki ana dili eğitimi ile sınırlandırılmıştır. Buradan hareketle bu çalışmada öncelikle, Japonya Eğitim, Kültür, Spor, Bilim ve Teknoloji Bakanlığı (MEXT) resmi sitesinde bulunan ilkokul öğretim programı temel alınarak ilkokul ana dili derslerinin amaç ve içerikleri betimlenmekte ve ardından ana dili eğitiminin ilk adımı ${ }^{1}$ olan İlkokul 1. sınıf ana dili ders kitabı şekil ve içerik açısından incelenmektedir.

Bu noktada öncelikle açıklığa kavuşturulması gereken önemli bir ayrıntı bulunmaktadır. Japon dilinin söz varlığında "Japonca" anlamında iki farklı sözcük yer almaktadır. Bu sözcükler "Kokugo" "ve "Nihongo" sözcükleridir. Sözlükte (Nihongo Daijiten ${ }^{3}, 2014$; s. 795) "national language" yani "ulusal dil" olarak tanımlanan Kokugo sözcüğ̈̈ ${ }^{4}$ Japon devletinin ulusal dili olması yönüyle siyasal bir kimliğe sahip olup, bu açıdan bakıldığında Nihongo sözcüğünden ayrılmaktadır (Lee, 2007; Tekmen ve Takano, 2016). Ramsey, Kokugo sözcügünün "bizim dilimiz, bizim ana dilimiz" anlamını içerdiğini belirtmektedir (2004: 82). Bununla paralel olarak, Japonya'da okullardaki ana dil derslerinin adı da Kokugo'dur. Diğer taraftan, Japoncayı yabancı dil olarak öğrenen birisi için bu dilin adı Nihongo'dur. Örneğin, Nihongo Gakkō (Japonca Okulu) denildiğinde, bu ifade Japoncayı ikinci dil olarak öğrenen birisinin gittiği okulu işaret etmektedir. Sonuç olarak, Kokugo sözcügünü Japonların ana dili olan Japonca ile sınırlandırmak mümkündür (Lee, 2007; Furuya, 2007; Inukai, 2007).

Çalışmanın bundan sonraki bölümlerinde Kokugo sözcügünün karş1lığı olarak "Japonca" ve "ana dili" sözcükleri kullanılmaktadır. Bu çalışma, ana dil olarak Japonca öğretimi ile sınırlandırıldığından metin içerisinde geçen "Japonca" ana dil konuşucuları tarafından kullanılan Japon dilini ifade etmektedir.

Türkiye'deki Japonya çalışmalarına bakıldığında, alan yazında Japonya'daki ana dili eğitimine ilişkin herhangi bir çalışma bulunmadığı görülmektedir. Bu çalışmanın, eksikliği hissedilen boşluğu doldurma yolunda bir ön adım olacağ 1 ve bu açıdan alana katkı sağlayacağı düşünülmektedir.

\section{Japonya'da Ana Dili Eğitimi ve Ana Dili Dersinin Programa Eklenmesi}

Hangi dil olursa olsun ana dili eğitiminin amacı, ana dilin sözcüklerini, dilbilgisini, deyimlerini, telaffuzunu vb. öğrenmek ve buna bağlı olarak dinleme, konuşma, okuma ve yazma gibi dil becerilerini edinmektir. Bu amaç Japonya'daki ana dili eğitimi için de elbette aynıdır. Fukawa, "modern bir ulus kurmak için standart bir dilin gerekliliği” görüşünün ortaya atılması ile ana dili eğitimi konusunun önem kazandığını belirtmektedir (2007, s. 76). Japonya'da ana dili eğitimi ilk olarak1920'li yıllarda ortaya atılmış olsa da bu eğitimin bilimsel olarak ele alınışının 1930 yılından itibaren olduğunu belirten Noji (1974) ise, ana dili ediniminin diğer birçok konunun öğrenilmesinde temel oluşturduğunu belirtmektedir.

1886 yılındaki ilkokul ve ortaokul yönetmeliğinde yeni derslerin oluşturulması konusu gündeme gelmiştir ancak ilkokula ana dili dersinin eklenmesi konusu ilk olarak 1900 yılında ilkokul yönetmeliğinin revize edilmesiyle olmuştur (Lee, 2007, s. 25; Fukawa, 2007, s. 79). Bu zamana kadar Japonca adlı bir dersin olmaması ana dili derslerinin olmaması anlamına gelmemelidir. Fukawa (2007, s. 79), ana dili dersinden önce, bu ders ile benzer içeriğe sahip "okuma”, "kompozisyon", "yazı" gibi derslerin olduğunu dile getirmektedir. Japonya'daki ilkokullar için ortak bir ana dili ders kitabının basılması ise 1903 yılında olmuştur (İrim ve Özbek, 2018, s. 34)

Günümüz Japon eğitim sistemine bakıldığında, ilkokul, ortaokul ve liselerde ana dili dersinin bulunduğu görülmektedir. Japonya Eğitim, Kültür, Spor, Bilim ve Teknoloji Bakanlığı (MEXT) resmi sitesinde bulunan öğretim

\footnotetext{
${ }^{1}$ Güleç ve Demirtaş (2012: 75), 6-12 yaş aralığındaki çocukların ilköğretim çağında oldukları göz önüne alındığında bu dönemde verilecek olan ana dili eğitiminin, çocuğun ileri yaşlardaki dil kullanma becerisini doğrudan etkileyeceğini söylemektedir.

${ }^{2}$ Bu sözcük, sadece Japon dili ile sınırlı olmayıp yazı sistemi olarak Çince karakterlerini kullanan bazı dillerin sözvarlığında da bulunmakta ve Japoncada olduğu gibi diğer dillerde de her ülkenin kendi ana dilini ifade etmektedir (Furuya, 2007, s. 32-37). Japonya'da kokugo sözcüğü, Meiji dönemi (1868 - 1912) ile birlikte, Kokugo dersinin de eğitim sistemine eklenmesi ile daha sik duyulur ve geniş çevrelerce bilinir hale gelmiştir.

${ }^{3}$ Japonca Büyük Sözlük (Ing: An Encyclopedia of Japanese Language and Literarute)

${ }^{4}$ Türkiye'de bu güne kadar yapılmış çalışmalara bakıldığında Kokugo sözcüğü her ne kadar anlamsal açıdan ele alınmamış olsa da, yeri geldikçe bu sözcüğün karşılığı olarak "ulusal dil" (Özrenk Aydın, 2010 ), "Japon dili / devlet dili" (İrim ve Özbek, 2018) ve "Japonca" (Özşen, 2020) gibi sözcüklerin kullanıldı̆̆ı görülmektedir.
} 
programı incelendiğinde, bu derslerin amaç ve içeriklerinin her kademede ve her sınıfta oldukça ayrıntılı bir şekilde düzenlendiği görülmektedir.

\section{İlkokuldaki Ana Dili Derslerinin Amaçları ve İçerikleri}

Bu çalışmada, ilkokuldaki ana dili derslerinin amaç ve içerikleri Japonya Eğitim, Kültür, Spor, Bilim ve Teknoloji Bakanlığı (MEXT) resmi sitesinde bulunan ilkokul öğretim programı ${ }^{5}$ temel alınarak betimlenmektedir.

\section{İlkokul Ana Dili Derslerinin Amaçları}

Sonuncusu 2017 yılında yayımlanan ilkokul öğretim programına göre ana dili dersinin amacı Japoncayı doğru şekilde anlama ve ifade etme nitelik ve becerilerinin geliştirilmesidir. Bu genel amaç öğretim programında aşağıdaki 3 madde $^{6}$ ile ayrıntılandırılmaktadır.

1) Günlük yaşam için gerekli olan ana dilin özelliklerini anlayıp, onu uygun şekilde kullanır hale gelmek.

2) Günlük yaşamda insanlarla ilişkilerde iletişim gücü becerilerini artırmak, düşünme ve hayal kurma becerilerini geliştirmek.

3) Sözcüklerin sahip olduğu güzelliği algılamakla birlikte, dil duygusunu benimseyip, ana dilin önemini fark ederek, ona saygı duymak ve bu yetenekleri iyileştirmeye yönelik bir tutum geliştirmek. sunulmaktadır.

Bahsi geçen öğretim programında ilkokulun farklı sınıflarında ana dili dersinin amaçları tablo halinde

Tablo 1. İlkokul Japonca Derslerinin Amaçları ${ }^{7}$

\begin{tabular}{|c|c|c|c|}
\hline & 1. Sinif ve 2. Sinif & 3. Sinif ve 4. Sinif & 5. Sinif ve 6. Sinif \\
\hline Bilgi ve Beceriler & $\begin{array}{l}\text { Günlük yaşam için gerekli olan } \\
\text { anadil bilgi ve becerilerini } \\
\text { kazanmakla beraber Japonya'nın dil } \\
\text { kültürünü tanıyıp anlayabilir hale } \\
\text { gelmek. }\end{array}$ & $\begin{array}{l}\text { Günlük yaşam için gerekli olan anadil } \\
\text { bilgi ve becerilerini kazanmakla } \\
\text { beraber Japonya'nın dil kültürünü } \\
\text { tanıyıp anlayabilir hale gelmek. }\end{array}$ & $\begin{array}{l}\text { Günlük yaşam için gerekli olan anadil } \\
\text { bilgi ve becerilerini kazanmakla } \\
\text { beraber Japonya'nın dil kültürünü } \\
\text { tanıyıp anlayabilir hale gelmek. }\end{array}$ \\
\hline $\begin{array}{l}\text { Düşünme gücü, } \\
\text { değerlendirme } \\
\text { gücü, ifade gücü } \\
\text { vb. }\end{array}$ & $\begin{array}{l}\text { Olayları sıraya koyarak düşünme, } \\
\text { hissetme ve hayal etme gücünü } \\
\text { geliştirip, günlük yaşamda insanlarla } \\
\text { ilişkilerde iletişim kurma gücünü } \\
\text { artırmak, kendi düşünce ve } \\
\text { fikirlerine sahip olmak. }\end{array}$ & $\begin{array}{l}\text { Mantıklı düşünme, yoğun hissetme ve } \\
\text { hayal etme gücünü geliştirip, günlük } \\
\text { yaşamda insanlarla ilişkilerde iletişim } \\
\text { kurma gücünü artırmak, kendi düşünce } \\
\text { ve fikirlerini toparlayabilir hale } \\
\text { gelmek. }\end{array}$ & $\begin{array}{l}\text { Mantıklı düşünme, yoğun hissetme ve } \\
\text { hayal etme gücünü geliştirip, günlük } \\
\text { yaşamda insanlarla ilişkilerde iletişim } \\
\text { kurma gücünü artırmak, kendi düşünce } \\
\text { ve fikirlerini toparlayabilir hale } \\
\text { gelmek. }\end{array}$ \\
\hline $\begin{array}{l}\text { Öğrenmeye yönelik } \\
\text { güç, insan doğası } \\
\text { vb. }\end{array}$ & $\begin{array}{l}\text { Dilin güzelliğini hissetmekle } \\
\text { beraber, eğlenerek okuma yapıp, ana } \\
\text { dile önem verip, düşünce ve fikirleri } \\
\text { karş1lıklı iletme tutumu geliştirmek. }\end{array}$ & $\begin{array}{l}\text { Sözcüklerin sahip olduğu güzelliği fark } \\
\text { etmekle birlikte, kapsamlı okuma } \\
\text { yapıp, ana dile önem verip, düşünce ve } \\
\text { fikirleri karş1lıklı iletme tutumu } \\
\text { geliștirmek. }\end{array}$ & $\begin{array}{l}\text { Sözcüklerin sahip olduğu güzelliği } \\
\text { anlamakla birlikte, ileri okuma } \\
\text { yapmak, ana dilin önemini kabul edip } \\
\text { düşünce ve fikirleri karş1lıklı iletme } \\
\text { tutumu geliștirmek. }\end{array}$ \\
\hline
\end{tabular}

Yukarıdaki tablo ve öğretim programının geneli incelendiğinde, tüm sınıflar için ana dili dersinin genel amacı elbette öğrencilerin dinleme, konuşma, okuma ve yazma dil becerilerini kazanmasıdır. Ancak sınıflara göre dil becerileri ile ilgili amaçların biraz değiştiği görülmektedir. 1. ve 2. sınıfta öğrencilerin olayları sıraya koyarak konuşmaları ve bir sıra takip ederek cümle ve paragraf yazma becerisi kazanmaları ön plana çıkmaktadır. Ayrıca ilk 2 sınıfta öğrencilerin okuma alışkanlığı kazanmaları için eğlenerek okuma yapma konusu vurgulanmaktadır. Bununla birlikte 1. ve 2. sınıfta hayal gücünün geliştirilmesi amacı önem taşımaktadır. 3. ve 4. sınıfta da ana dili dersinin amaçları önceki iki sınıfla benzerlik göstermektedir. Ancak mantıklı düşünme ve konuşma, ana dilin önemini fark etme, kendi düşünce ve fikirlerini karşıya iletme gibi amaçların eklendiği görülmektedir. 5. ve 6. sınıf ana dili derslerinde ise, önceki sınıflardan farklı olarak daha uzun metinlerin okunması, içerik ve ana fikrin tespit edilmesi amaçlanmaktadır. Ancak tüm sınıflar için ortak bir amaç dikkat çekmektedir. Bu amaç ana dilin öneminin fark edilmesi, dilin gücünün ve güzelliğinin anlaşılmasıdır.

\footnotetext{
${ }^{5}$ Bakanlık resmi sitesinde her kademe, her sınıf ve her ders için ayrı ayrı öğretim programları bulunmaktadır. Bu çalışmanın konusu ilkokul Japonca dersi olduğu için sadece ilkokul Japonca dersi için en son yayımlanan öğretim programından yararlanılmıştır.

https:/www.mext.go.jp/component/a_menu/education/micro_detail/_icsFiles/afieldfile/2019/03/18/1387017_002.pdf

${ }^{6}$ Yazar tarafından Japonca aslından çevrilmiştir.

${ }^{7}$ Yazar tarafından Japonca aslından çevrilmiştir. (Alıntılanan kaynak:

https://www.mext.go.jp/component/a_menu/education/micro_detail/_icsFiles/afieldfile/2019/03/18/1387017_002.pdf
} 


\section{İlkokul Ana Dili Derslerinin İçeriği}

Ana dili derslerinin içeriğini oluşturan konular ana dili derslerinin amaçları ile paralel olarak şekillenmektedir. Bu konular öğretim programında temel olarak aşağıdaki şekilde sıralanmaktadır.

1) Dilin özellikleri ve kullanımları ile ilgili konular

2) Bilginin ele alınış şekilleri ile ilgili konular

3) Ülkenin dil kültürü ile ilgili konular

$\mathrm{Bu}$ üç konu da kendi içerisinde çeşitli alt başlıklara ayrılmaktadır. Dilin özellikleri ve kullanımları ile ilgili konular, "sözcüklerin ișlevi", "konuşma dili ve yazı dili", "Kanji ${ }^{8} "$, "sözvarlığı", "cümleler ve metinler", "ifade becerisi" gibi alt başlıklardan oluşmaktadır.

$\mathrm{Bu}$ alt başlıkların ne ifade ettiği öğretim programında tek tek açıklanmaktadır. Örneğin kaçıncı sınıfta kaç Kanji öğretileceği aşağıdaki tablodaki gibi gösterilmektedir.

Tablo 2.İlkokulda Öğretilecek Kanji Sayılarının Sınıflara Göre Dağılımı ${ }^{9}$

\begin{tabular}{|c|c|c|c|c|c|c|c|}
\hline & 1. Sinif & 2. Sinif & 3. Sinif & 4. Sinif & 5. Sinif & 6. Sinif & Toplam \\
\hline 2008 yılı Öğretim Programı & 80 Kanji & 160 Kanji & 200 Kanji & 200 Kanji & 185 Kanji & 181 Kanji & 1006 Kanji \\
\hline 2017 yılı Öğretim Programı & 80 Kanji & 160 Kanji & 200 Kanji & 202 Kanji & 193 Kanji & 191 Kanji & 1026 Kanji \\
\hline Artış / Azalış & 0 & 0 & 0 & +2 & +8 & +10 & +20 \\
\hline
\end{tabular}

Yukarıdaki tabloda sayıları belirtilen Kanjilerin yazılış sıralarının öğretilmesi ve bu Kanjilerin cümle içinde kullanılması ana dili dersinin amaçları ve içerikleri arasındadır. Ayrıca yazı yazmak için kullanılan kalem, firça gibi araç gereçlerin doğru tutulması, Kanjilerin boyutları ve yönleri gibi ayrıntılar ana dili derslerinin içeriklerinden bazılarıdır.

Öğretim programında her sınıf için ana dili derslerinin içeriklerinin ayrıntılı şekilde ele alındığı görülmektedir. İçeriklerin sınıflara göre dağılımına aşağıdaki tabloda genel hatları ile yer verilmektedir.

Tablo 3. İlkokul Japonca Derslerinin İçerikleri

\begin{tabular}{|c|c|c|c|}
\hline & 1. Sinif ve 2. Sinif & 3. Sinif ve 4. Sinif & 5. Sinif ve 6. Sinif \\
\hline $\begin{array}{l}\text { Ders } \\
\text { içerikleri }\end{array}$ & $\begin{array}{l}\text { Öğrencileri belirli bir konuda } \\
\text { konuşmaya teşvik etmek } \\
\text { Kibar ve samimi ortamlara göre } \\
\text { konuşmak } \\
\text { Telaffuza ve ses tonuna dikkat } \\
\text { etmek } \\
\text { Soru sormak } \\
\text { Cevap vermek } \\
\text { İnsanları selamlamak } \\
\text { Tutarlı cümleler ve paragraflar } \\
\text { yazmak } \\
\text { Yüksek sesle okumak } \\
\text { Okuduğunu anlamak }\end{array}$ & $\begin{array}{l}\text { Sözcüklerin, düşünceleri ifade etmekteki } \\
\text { işlevinin farkına varmak } \\
\text { Karşıdakine bakarak konuşmak } \\
\text { Dinlerken sözcüklerin vurgusuna ve dilin } \\
\text { kullanımına dikkat etmek } \\
\text { Yazım biçimlerinin kullanımı ile ilgili } \\
\text { çalışmalar yapmak } \\
\text { Noktalama işaretlerini kullanmak } \\
\text { Sözcük bilgisini artırmak } \\
\text { Sözcüklerin, cümlelerin ve paragrafların } \\
\text { görevlerini anlamak } \\
\text { Cümlenin genel yapısıı ile içeriğinin } \\
\text { farkında olarak yüksek sesle okumak } \\
\text { Karşılaştırma ve sınıflandırma yapmak } \\
\text { Sözlük kullanmak } \\
\text { Kolay edebi metinler okumak ve } \\
\text { ezberlemek } \\
\text { Deyim ve atasözlerinin anlamını öğrenip, } \\
\text { kullanmak }\end{array}$ & $\begin{array}{l}\text { Sözcüklerin karşıdaki ile bağlantı kurma } \\
\text { işlevini fark etmek } \\
\text { Yazı dili ile konuşma dili arasındaki farkı } \\
\text { görmek } \\
\text { Kanji ve Kana }{ }^{10} \text { yazım biçimlerini uygun } \\
\text { olarak kullanmak ve doğru yazmak } \\
\text { Sözcük bilgisini artırmak } \\
\text { Günlük hayattaki saygı dilini anlayıp } \\
\text { kullanımına alışmak } \\
\text { Mecazlar gibi dilin ifade zenginliğini fark } \\
\text { etmek } \\
\text { Metinleri yüksek sesle okumak } \\
\text { Sebep sonuç ilişkilerini anlamak } \\
\text { Klasik metinleri anlatan yazıları okuyup } \\
\text { anlamak } \\
\text { Eskiden yaşamış insanların bakış açılarını ve } \\
\text { hislerini anlamak } \\
\text { Sözcüklerin kökeni ve zaman içindeki } \\
\text { değişimlerini anlamak } \\
\text { Karakterleri doğru ve orantılı yazmak } \\
\text { Okuma ve yazma alışkanlığının düşünce } \\
\text { dünyasını genişlettiğini fark etmek }\end{array}$ \\
\hline
\end{tabular}

\footnotetext{
${ }^{8}$ Japoncadaki 3 yazı biçiminden biri olup, Çince kökenli imlere verilen addır (Tekmen ve Takano, 2016).

${ }^{9}$ Yazar tarafından Japonca aslından çevrilmiştir. (Alıntılanan kaynak:

https://www.mext.go.jp/component/a_menu/education/micro_detail/_icsFiles/afieldfile/2019/03/18/1387017_002.pdf, s. 18, Erişim Tarihi: 01.09.2020)

${ }^{10}$ Japoncadaki 3 yazım biçiminden ikisi olan Hiragana ve Katakana yazım biçimlerini kapsayan genel addır.
} 
İlkokul 1. Sınıf Japonca Ders Kitabının Şekil ve İçerik Açısından İncelenmesi

Bu bölümde şekil ve içerik açısından ele alınacak ilkokul 1. sınıf Japonca ders kitabı 2012 yılında Mitsumura Tosho yayınevi ${ }^{11}$ tarafından basılmıs 2 ciltten oluşan bir kitaptır. Kitabın şekli ve içeriği ile ilgili özellikler aşağıda ele alınmaktadır.

\section{Ders Kitabının Şekilsel Özellikleri}

Kitap 25x17,5 cm boyutlarında, renkli lüks karton kapağa sahiptir. 2 ciltlik kitabın 1. cildi 124 sayfadan, 2. cildi ise 132 sayfadan oluşmaktadır. Sayfalar parlak kuşe kağıttır.

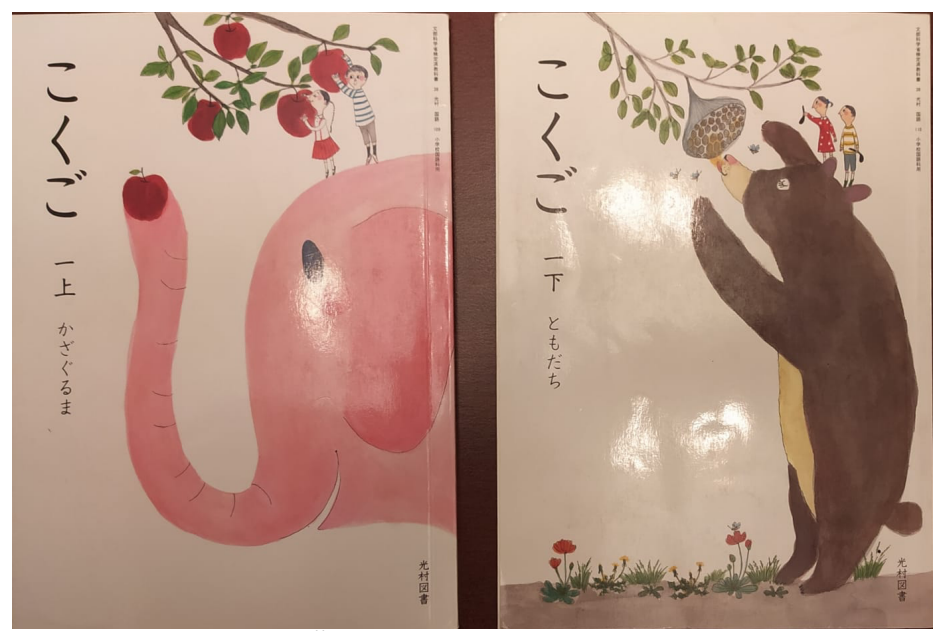

Görsel 1. Ders Kitabının Ön Kapakları (soldaki 1. Cilt - sağdaki 2. Cilt)

Görsel 1'de de görüldüğü gibi kitap kapakları oldukça renkli ve ilgi çekici olarak hazırlanmıştır. Her iki kapakta da çocuklar, hayvanlar, ağaç dalları, meyve ve çiçeklere yer verildiği görülmektedir. Parlak ve renkli kapak, kitabın albenisini artıırken aynı zamanda içerik ile ilgili merak uyandırmaktadır.

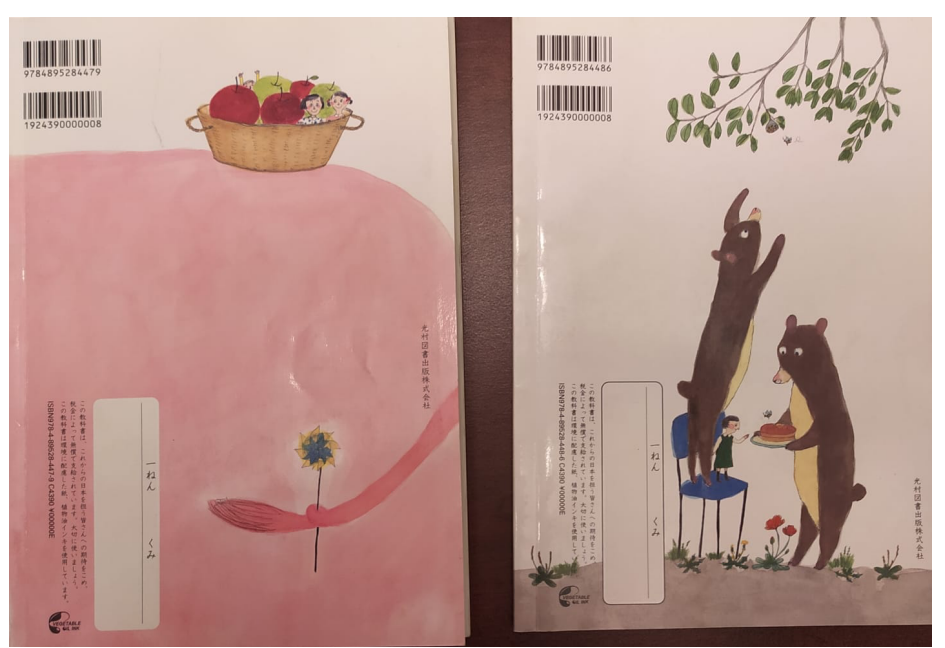

Görsel 2: Ders Kitabının Arka Kapakları (soldaki 1. Cilt - sağdaki 2. Cilt)

Görsel 2'de ders kitaplarının arka kapakları sunulmaktadır. Ön kapakta yer alan resimlerin arka kapakta devam ettiği dikkat çekmektedir. Kitabın sonraki sayfaları incelendiğinde, kitap içerisinde bol bol resim bulunduğu, yazıların büyük ve okunaklı olduğu, sözcüklerden cümlelere, cümlelerden metinlere doğru aşamalı bir ilerleyişin olduğu görülmektedir.

Ayrıca kitaplar büyüklük açısından değerlendirildiğinde, kitapların normal boyuta sahip olduğu görülmektedir. $\mathrm{Bu}$ durumun kitapları gerek taşıma gerek kullanım açısından kullanışlı hale getirdiği düşünülmektedir.

\footnotetext{
${ }^{11} \mathrm{Bu}$ yayınevi, Ishihara (2009) tarafından ilkokul ana dili ders kitapları konusunda en başarılı yayınevi olarak belirtilmektedir.
} 
Varoğlu

\section{Ders Kitabının İçerik Özellikleri}

1. cildin dış kapağı açıldığında, hemen iç kapakta bir şiir bulunmaktadır.

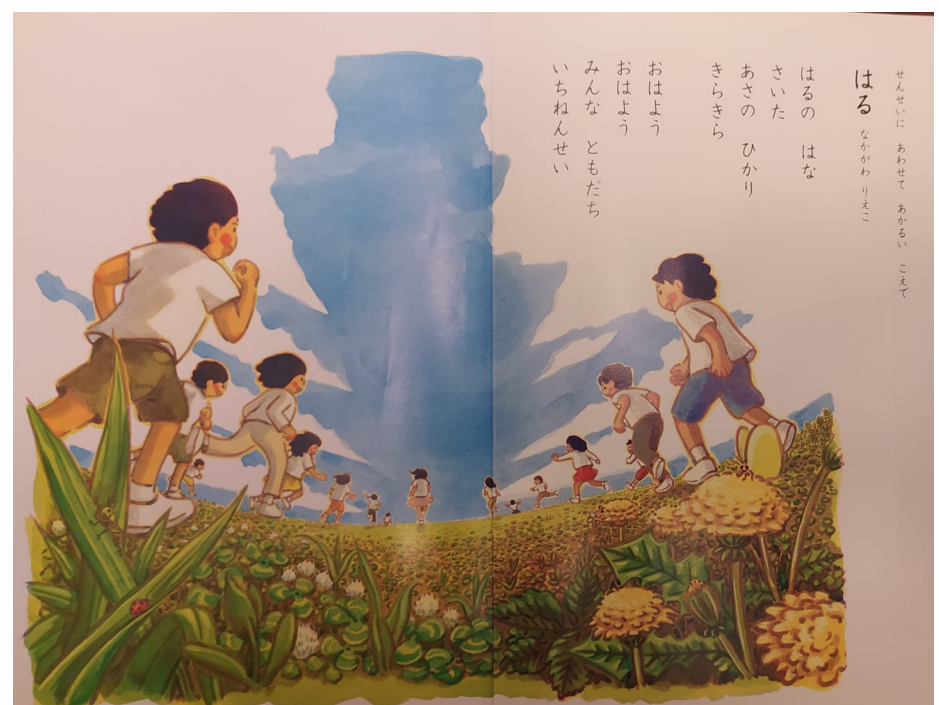

Görsel 3: Ders Kitabının İç Kapağı (1. Cilt s. 1)

"Bahar" (Haru) başlığını taşıyan bu şiirin aslı ve çevirisi aşağıdaki gibidir:

Haru no hana

Bahar çiçekleri

Saita

Asa no hikari

Açt1

Kira kira

Sabah 1şı̆̆1

Piril piril

$\begin{array}{ll}\text { Ohayō } & \text { Günaydın } \\ \text { Ohayō } & \text { Günaydın } \\ \text { Minna tomodachi } & \text { Hepimiz arkadaşız } \\ \text { Ichinen sei } & \text { 1. sinıflar }\end{array}$

Çok basit gibi görünen bu şiirin birçok anlam içerdiği düşünülmektedir. Öncelikle şiirin bahar ile ilgili olmas1 mevsimin bahar olmasından kaynaklanmaktadır. Japonya'da yeni okul dönemi Nisan ayında başlamaktadır. Dolayısıyla bu şiirle birlikte baharın, çiçeklerin, içinde olunan zamanın güzelliğinin vurgulandığı söylenebilir. "Günaydın" sözcüklerinin tekrarlanması ile selamlaşmanın öneminin vurgulandığı, "hepimiz arkadaşız" ifadesi ile de arkadaşlıkla ilgili farkındalık oluşturulduğu düşünülmektedir. Bu şiirin bulunduğu sayfalardaki resme bakıldığında ise aynı yöne koşan çocuklar görülmektedir.

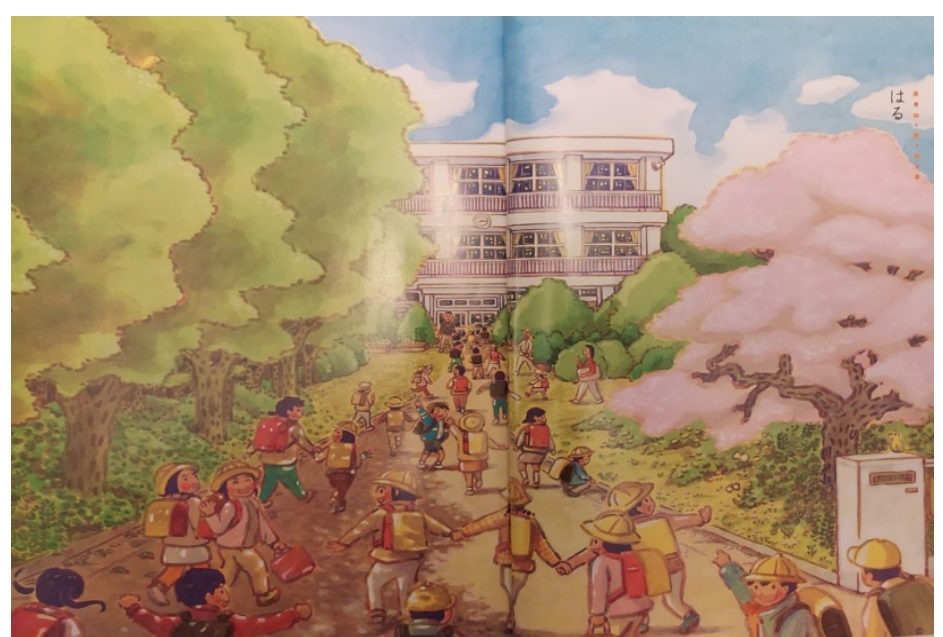

Görsel 4: Ders Kitab1 (1. Cilt s. 2-3) 
Görsel 4'te ise okulun ilk günü gülümseyen yüzlerle, el ele okula doğru koşan 1. sınıf öğrencileri görülmektedir. Bu sayfalarda herhangi bir yazı olmayıp sadece sağ üst köşede "bahar"(haru) sözcügü bulunmaktadır. Bu sözcüğün önceki sayfadaki şiire gönderme yaptığı düşünülmektedir.

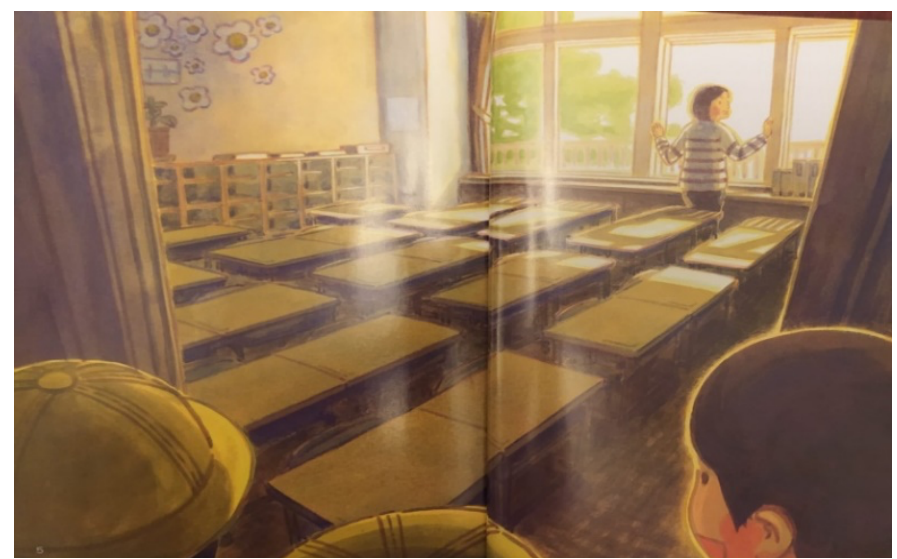

Görsel 5: Ders Kitabı (1. Cilt s. 4-5)

Görsel 5'te ise sınıfta pencereden dişarıya bakan bir öğretmen görülmektedir. $\mathrm{Bu}$ öğretmen sanki öğrencilerinin sınıfa gelişlerini beklemektedir. Sınıfın kapısında ise birkaç öğrenci görünmektedir. Bu sayfalarda da herhangi bir yazı bulunmamaktadır.

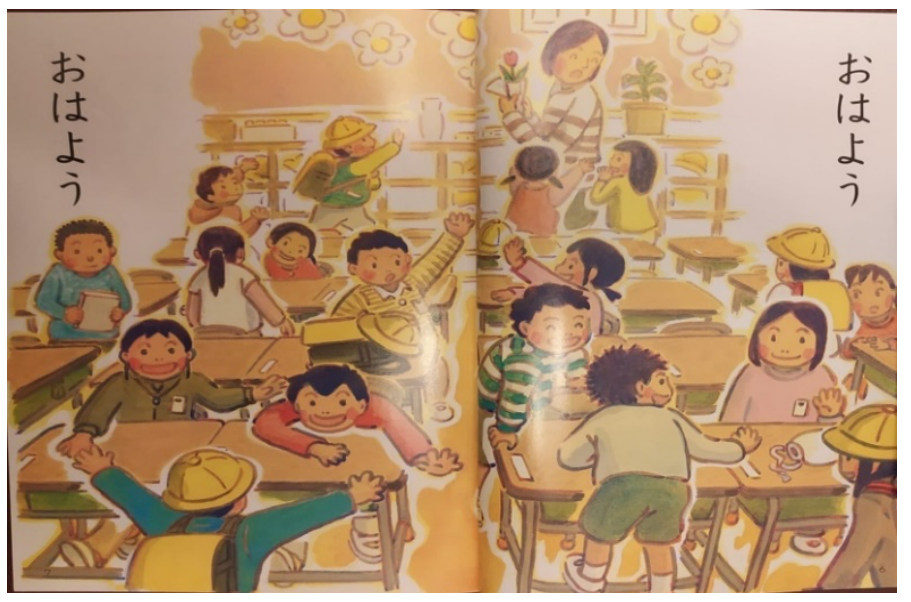

Görsel 6: Ders Kitabı (1. Cilt s. 6-7)

Görsel 6'da öğrencilerin sınıfta olduğu görülmektedir. Öğretmen de dahil herkesin bir şeylerle meşgul ve mutlu olduğu yansımaktadır. Sayfaların sağ ve sol üst köşelerinde "günaydın"(ohayou) yazısı dikkat çekmektedir.

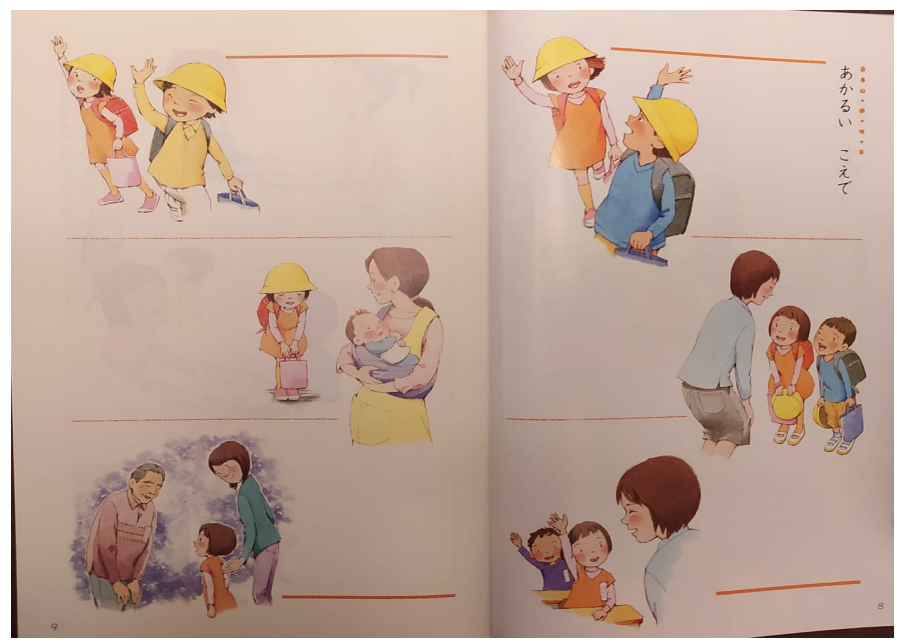

Görsel 7: Ders Kitabı (1. Cilt s. 8-9) 
Görsel 7'de ise çeşitli selamlama ifadelerinin kullanımını gerektiren farklı ortamlara ait resimler görülmektedir. Sayfanın sağ üst köşesinde ise "canlı bir sesle"(akarui koe de) ifadesi bulunmaktadır. Bu sayfa ile öğrencilere kimleri, ne zaman, nasıl selamlayacakları konusunun öğretilmesinin amaçlandığı düşünülmektedir.

Buraya kadar ele alınan görseller tekrar değerlendirildiğinde, hepsinin birbirini takip eder nitelikte, sanki bir öykünün ilerleyişini anlatır şekilde sıralandıkları dikkat çekmektedir. Bu resimlerle, öğrencilere öncellikle okul ve arkadaşlık sevgisinin aşılanmaya çalışıldığını söylemek mümkündür. Sonrasında ise sosyal hayatın en temel öğesi ve iletişimin ilk adımı olan selamlama sözcüklerinin öğretimi konusu gelmektedir. Selamlaşma bütün toplumlarda iletişime başarılı bir giriş yapmak ve iletişimi sağlıklı şekilde yürütmek için olmazsa olmaz bir önkoşuldur (Demir, 2012). Japon toplumunda da selamlama sözcükleri insan ilişkilerinin temelini oluşturmaktadır. Tekmen ve Takano, "İnsan ilişkileri selamlama ile başlar, selamlama ile biter" demekte ve selamlamanın basit selamlama sözcüklerinin ötesinde "özür dileme, teşekkür etme, rica etme" gibi çok daha geniş bir anlamı içerdiğini belirtmektedir (2016: 352).

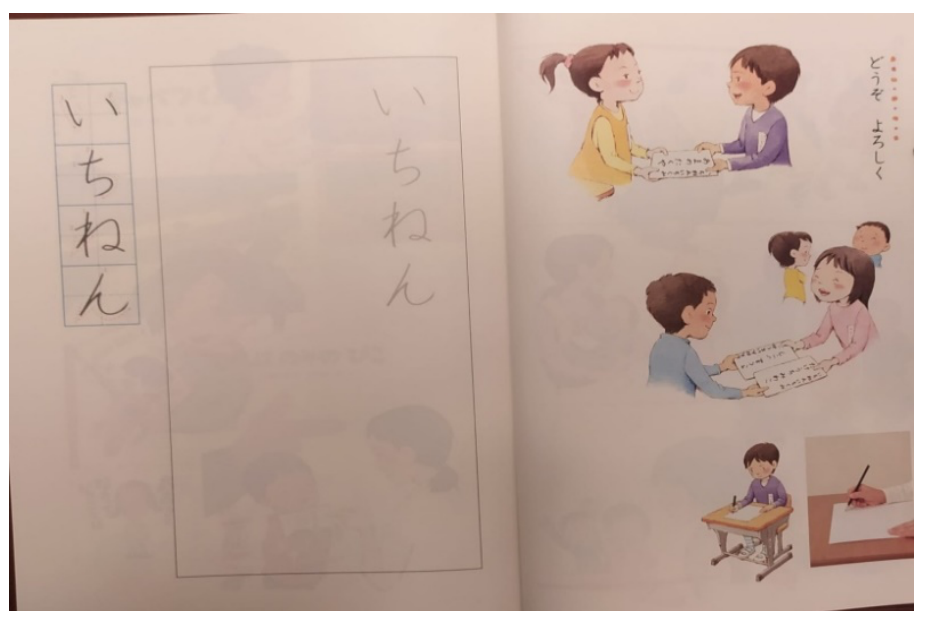

Görsel 8: Ders Kitabı (1. Cilt s. 10-11)

Selamlama ifadelerinin ardından tanışma konusu gelmektedir. Görsel 8'de öğrencilerin birbirleri ile tanıştıkları, tanışma sırasında birbirlerine bazı yazılar verdikleri görülmektedir. İletişimin başlangıcı sayılan selamlama ne kadar önemli ise kendini tanıtma yani karşılıklı tanışma da bir o kadar önemlidir. Özellikle Japoncada tanışma sırasında kullanılan kalıplaşmış ifadeler bulunmaktadır. Bu ifadeleri doğru şekilde kullanmak iletişimin başlaması ve devamı için büyük öneme sahiptir. Kitabın bu sayfası ile yazım biçimi çalışmalarına da başlandığı görülmektedir.

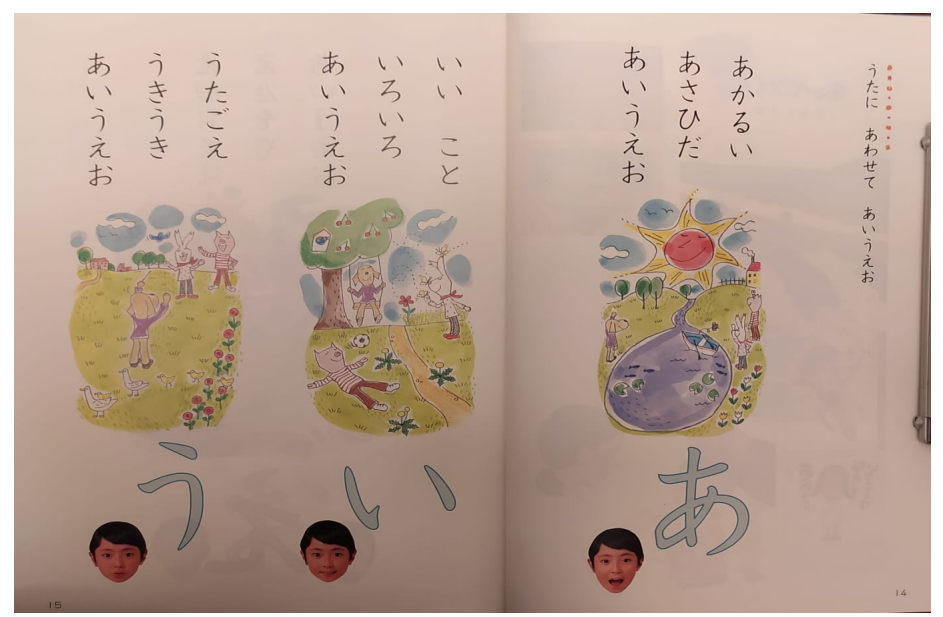

Görsel 9: Ders Kitabı (1. Cilt s. 14-15)

Görsel 9'da kitabın 14. ve 15. sayfasından itibaren hiragana ${ }^{12}$ yazım biçiminin öğretilmeye başlandığı görülmektedir. Sayfaların altında öğretilecek olan "a-i-u" heceleri büyük şekilde yazılmakta, bu hecelerin altında ise bu hecelerin sesletiminde olması gereken ağız şekilleri gösterilmektedir. Sayfanın üst bölümünde ise bu hecelerin sık kullanıldığı şarkı sözleri yer almaktadır.

\footnotetext{
${ }^{12}$ Japoncadaki 3 yazım biçiminden biri olup, Japonca sözcük ve ekleri yazmak için kullanılan hece yazısıdır.
} 
Bu sayfalardan sonra 51. sayfaya kadar hiragana yazım biçiminin diğer hecelerinin çalışıldığı görülmektedir. Hecelerin yazılış ve okunuş çalışmaları yapılırken, yeni öğrenilen hecelerle ilgili yeni sözcüklerin eklendiği görülmektedir. Diğer taraftan yeni sözcüklerin anlamlarının resimlerle desteklendiğini söylemek mümkündür. Ayrıca, sözcükler ve cümleler haricinde ara ara kısa metinlere de yer verilmektedir. Kitap içerisinde, çizimler dışında gerçek hayvan resimleri ya da gerçek doğa resimleri de bulunmaktadır.

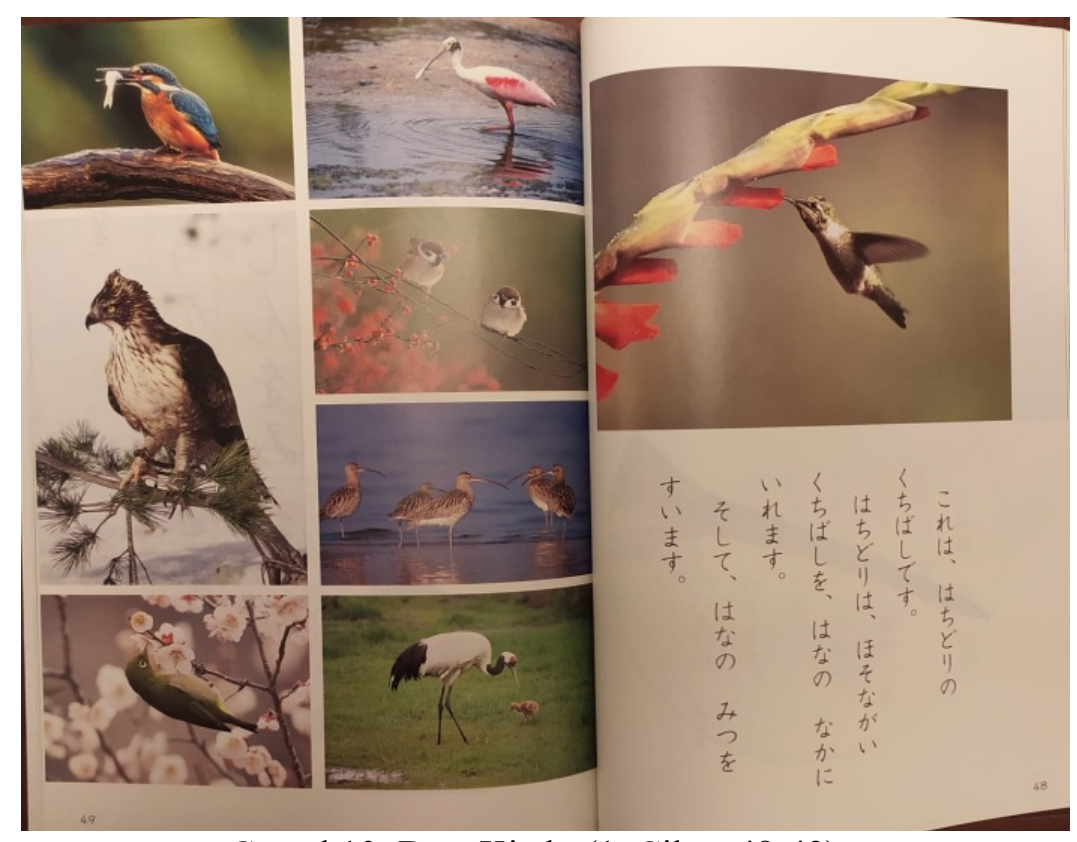

Görsel 10: Ders Kitabı (1. Cilt s. 48-49)

Görsel 10'da sağdaki sayfada resimdeki kuşun ne yapıyor olduğu ile ilgili bilgi verilmektedir. Soldaki sayfada da çeşitli gerçek kuş resimleri yer almaktadır. Bu şekilde öğrencilerin hayvanlara karşı ilgilerinin beslenmeye çalışıldığ1 düşünülmektedir.

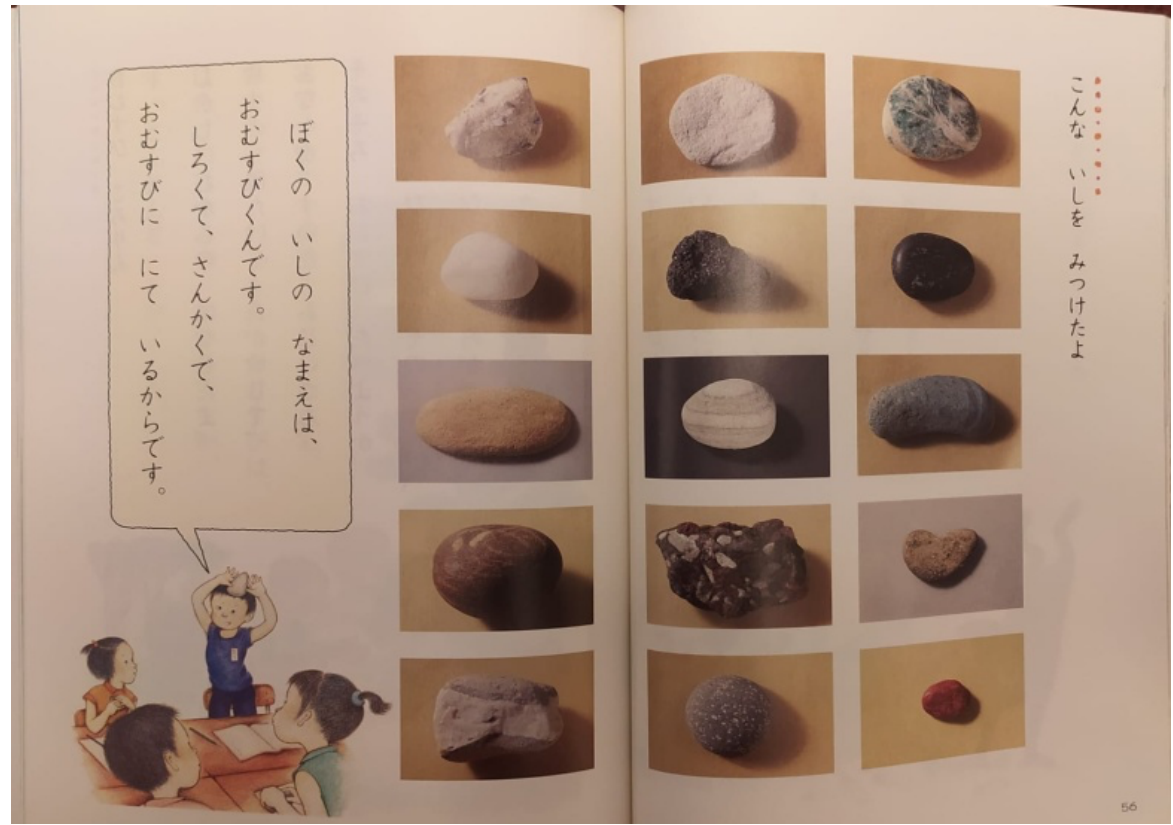

Görsel 11: Ders Kitab1 (1. Cilt s. 56-57)

Görsel 11 'de ise çeşitli taş resimleri görülmektedir. Görsel 10'da olduğu gibi bu sayfalarda da öğrencilerin doğaya karşı ilgi duymalarının sağlanmaya çalışıldığı düşünülmektedir. Sağ üst köşede "böyle bir taş buldum”(konna ishi wo mitsuketa yo) yazmaktadır. Solda yazanlar ise bir öğrencinin kendi taşını tanıtması ile ilgilidir. 


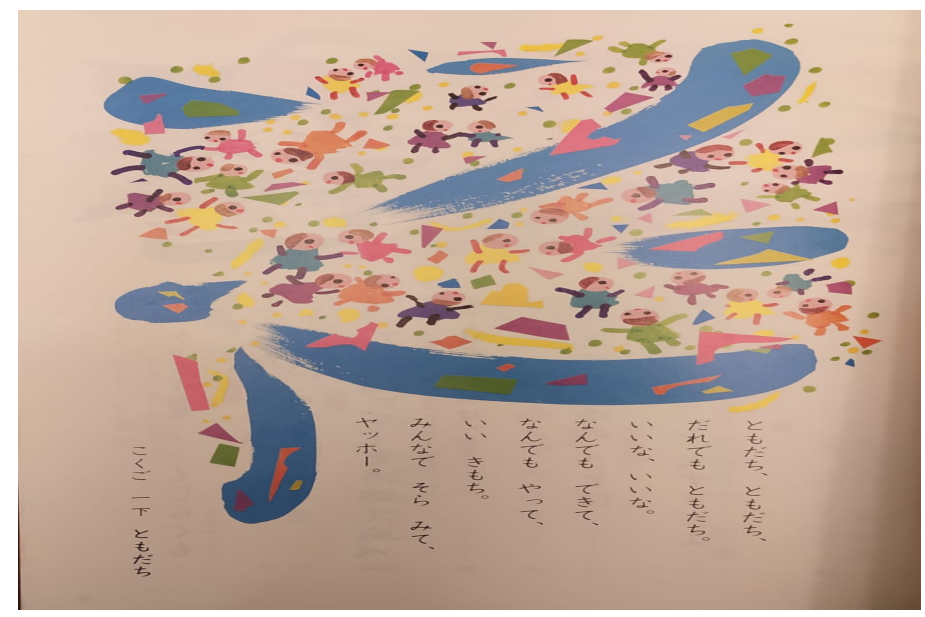

Görsel 12: Ders Kitabı (2. Cilt s. 1)

Görsel 12'de Japonca ders kitabının 2. cildinin ilk sayfası görülmektedir. İlk kitapta olduğu gibi, bu kitapta da bir şiirle başlangıç yapılmaktadır. "Arkadaş” (Tomodachi) başlığını taşıyan bu şiirin aslı ve çevirisi aşağıdaki gibidir:

Tomodachi, tomodachi,

Dare demo tomodachi,

Iina, Iina.

Nan demo dekite,

Nan demo yatte,

Ii kimochi.

Minna de sora wo mite,

Yahhō
Arkadaş, arkadaş

Hepimiz arkadaşız.

Ne iyi, ne iyi.

Her şeyi yapabilmek,

Her şeyi yapmak,

$\mathrm{Ne}$ iyi bir his.

Hep beraber gökyüzüne bakıp,

Yahoo (diyelim)

Ders kitabının her iki cildine de şiirle başlanması dikkat çekmektedir. Bu durum, öğrencilere az sözle çok şey anlatılmak istendiğini düşündürmektedir. Japon edebiyatına bakıldığında Japon şiir türlerinin dünya edebiyatını etkileyen önemli bir yere sahip olduğu görülmektedir (Tekmen, 2010). Buradan hareketle, ders kitaplarına şiirle başlanmasının ilkokulun 1. sınıfından itibaren öğrencilerde edebiyat bilincinin oluşturulması açısından önemli olduğu söylenebilir. Bu makalenin konusu olmamakla birlikte aynı yayınevine ait ilkokul Japonca ders kitaplarına da şiir ile başlanması gözden kaçırılmaması gereken bir ayrıntıdır.

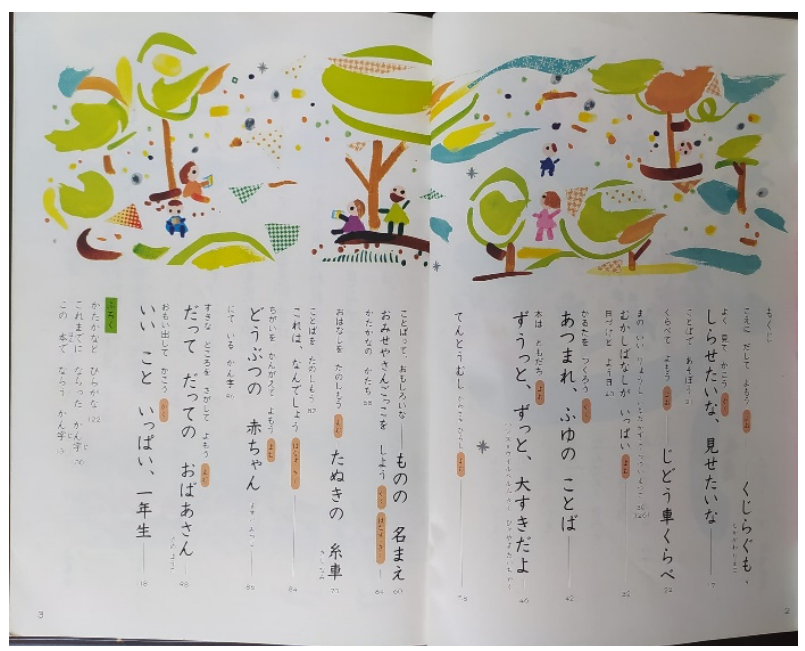

Görsel 13: Ders Kitabı (2. Cilt s. 2-3)

Görsel 13’te de görüldüğü gibi Japonca ders kitabının 2. cildinde 1. ciltten farklı olarak içindekiler bölümü yer almaktadır. İçindekiler bölümüne bakıldığında 2. ciltte 8 okuma, 3 yazma, 1 yazma-okuma-dinleme ve 1 de konuşmadinleme çalışması bulunduğu görülmektedir. Ana başlıklardan önce okuma yazma çalışmalarının hedeflerine yönelik ifadeler dikkat çekmektedir. Örneğin okuma çalışmaları için "yüksek sesle okuyalım", "karşılaştırarak okuyalım", "kitaplar arkadaşımız" vb., yazma çalışmaları için "iyice bakıp yazalım”, "oyun kartları hazırlayalım”, "hatırlayıp yazalım" vb. hedefler belirtilmiştir. 
Japonca ders kitabının 2. cildinden itibaren resimlerin azalarak yazıların çoğaldığı, dolayısıyla okuma çalışmalarına ağırlık verildiği söylenebilir. 2. cildin daha ayrıntılı bir şekilde incelenmesi için metinlerin içerik analizini yapmak mümkündür. Ancak bu çalışmada metinlerin incelenmesi amaçlanmadığından, metinlerin içerik çözümlemesi başka bir çalışmanın konusu olarak sonraki çalışmalara bırakılmıştır.

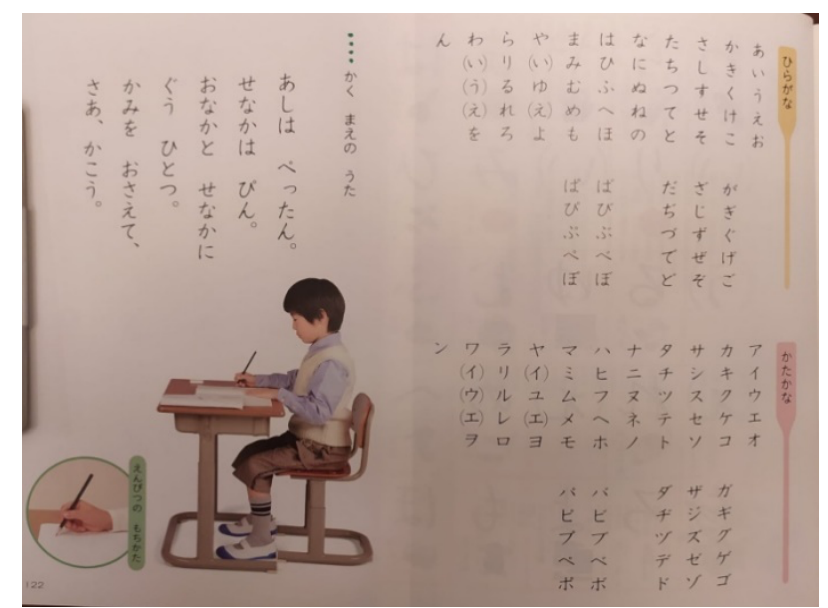

Görsel 14: Ders Kitab1 (1. Cilt s. 121-122)

Görsel 14, Japonca ders kitab1 1. cildinin sonuna eklenmiş olan $K a n a^{13}$ listesine aittir. Sol sayfada dikkat çeken nokta ise kalem tutuş şeklinin resim ile gösterilmesi ve doğru oturuş şekli ile ilgili bir şarkı bulunmasıdır.

\section{Değerlendirme}

Bu çalışmada, Japon dilinin sözvarlığında Japonca sözcüğünü karşılayan iki sözcük bulunduğu, bunlardan Nihongo sözcüğünün yabancılar için, Kokugo sözcüğünün ise ana dili konuşucuları için Japonca anlamını karşıladığ 1 vurgulanmıştır. Başka dillerde böyle bir durumla karşılaşmak pek mümkün değildir. Örneğin Türkçe açısından düşünüldüğünde anadili konuşucuları için de, Türkçeyi yabancı dil olarak öğrenen ya da konuşanlar için de bu dilin adı Türkçedir. Buradan hareketle, bu çalışma ile Kokugo sözcüğünün her şeyden önce Japon insanında "bizim dilimiz" algısı oluşturduğu ve dolayısıyla insanlara milli kimlik ve dil bilinci aşıladığı açıkça görülmektedir.

Kokugo aynı zamanda Japonya'da okullardaki ana dil derslerinin adıdır. Bu çalışmada, İlkokul 1. sınıf Japonca dersinin amaç ve içerikleri betimlenmiş, en son yayımlanan öğretim programına göre, ilkokul Japonca derslerinin genel amacının, Japoncayı doğru şekilde anlama ve ifade etme nitelik ve becerilerinin geliştirilmesi olduğu anlaşılmıştır. Bu betimlemenin ardından, İlkokul 1. Sınıf Japonca ders kitabı şekil ve içerik açısından incelenmiştir. $\mathrm{Bu}$ inceleme sonucunda, kitabın 1. cildinde kalem tutuş şeklinden telaffuza, ses tonundan, hecelerin sesletimi sırasındaki ağız şekillerine kadar birçok ayrıntıya yer verildiği görülmüştür. Bununla beraber aynı ciltte, insanları selamlama ya da tanışma gibi kültürel öğeler, arkadaşlığın öneminin vurgulanması, doğaya ve hayvanlara karşı duyarlılık kazandırılması gibi insani değerler öne çıkmaktadır. 2. ciltte ise okuma metinlerine ağırlık verildiği dikkat çekmektedir. Okuma ve yazma becerilerinin geliştirilmesine yönelik alıştırmalar her ne kadar ilk ciltte de bulunsa da 2. cilt ile beraber, okuduğunu anlama, yüksek sesle okuma ve yazma alıştırmalarının arttığı görülmektedir. Bu durum, 1. ciltte Japon dili ve kültürü ile ilgili farkındalık kazandırılmasının, 2. ciltte ise dil becerilerinin geliştirilmesinin amaçlandığını düşündürmüştür. Diğer taraftan, Japonca ders kitabının her iki cildine de şiir ile başlanması Japon kültürüne özgü önemli bir ayrıntı olarak değerlendirilmiştir.

Yazar çalışmanın tamamını gerçekleştirmiştir.

\section{Araştırmacıların Katkı Oranı}

\section{Destek ve Teşekkür}

Yazar çalışma için herhangi bir finansal destek almamıştır.

\section{Çıkar Çatışması}

Yazar çalışmada herhangi bir çıkar çatışmasının bulunmadığını beyan etmiştir.

\footnotetext{
${ }^{13}$ Bakınız dipnot 10
} 
Varoğlu

\section{Kaynakça / References}

Demir. M. (2012). Gündelik yaşamda selamlaşma ve yemek görgü kurallarının toplumlardaki farklılaşması. Folklor/Edebiyat, $18(70), 165-186$.

Güleç, İ.,\&Demirtaş, T. (2012). İlköğretim 8. sınıf ana dili ders kitapları üzerine karşılaştırmalı bir çalışma: Türkiye-Amerika Birleşik Devletleri örneği. Sakarya University Journal of Education, 2(1), 74-91.

Fukawa, G. (2007). Kokugo Kyōiku ni okeru "Kokugo" [Ana dil eğitiminde “Kokugo"]. Gengo, 36(1), 76-83.

Furuya, A. (2007). Kanji Bunka-ken to "Kokugo" [Kanji kültür alanı ve "Kokugo”]. Gengo, 36(1), 32-40.

Inukai, M. (2007). Kokugo Jisho no naka no "Kokugo” [Ulusal dil sözlüğü içerisinde "Kokugo”]. Gengo, 36(1), 68-75.

Ishihara, C. (2005). Kokugo Kyōkasho no Shisō [Ana dil ders kitabının ideolojisi]. Tōkyō: Chikuma Shobō.

Ishihara, C. (2009). Kokugo Kyōkasho no naka no Nihon [Ana dil ders kitabi içerisindeki Japonya]. Tōkyō: Chikuma Shobō.

İrim, N. B., \& Özbek, A. (2018). İkinci Dünya Savaşı ve öncesi Japon Dili Eğitimi Tarihi. Çanakkale: Paradigma Akademi.

Lee, Y. (2007). “Kokugo” to iu Kotoba no Atarashisa [“Kokugo” denen sözcügüun yeniliği]. Gengo, 36(1), $24-31$.

MEXT (2017). Shōgakkō Gakushū Shidō Yōryō Kaisetsu [İlkokul öğretim programı]. Erişim: https://www.mext.go.jp/component/a_menu/education/micro_detail/_icsFiles/afieldfile/2019/03/18/1387017_002.pdf

Mitsumura Tosho Shuppan Kabushikigaisha Henshū-bu. (2012). Kokugo 1 (Jō Kazaguruma / Ge Tomodachi): Shōgakkō Kokugokayō [Japonca 1 (1. cilt Yel Değirmeni /2. cilt Arkadaş: İlkokul ana dil dersi için]. Tōkyō: Mitsumura Tosho.

Noji, J. (1974). Kokugo Kyōikugakushi [Ana dil ě̆itimi tarihi]. Tōkyō: Kyobunsha.

Özrenk Aydın, G. (2010). Türkiye'deki ve Japonya'daki dil politikalarına genel bakış (Yayınlanmamış yüksek lisans tezi). Ankara Üniversitesi, Ankara.

Özşen, T. (2020). Modern Japon Eğitim Sisteminin eğitim tarihi temelleri üzerine değerlendirme: Meiji'den Shōwa'ya 1868-1950 arası döneme bakış. Eğitimde Kuram ve Uygulama, 16(1), 36-52.

Ramsey, S. R. (2004). The Japanese language and the making of tradition. Japanese Language and Literature, 1, 81-110.

Satō, T., Maeda, T. (2014). Nihongo Daijiten An Encyclopedia of Japanese Language and Literarute. Tōkyō: Asakura Shoten.

Sinan, A. T. (2006). Ana dili eğitimi üzerine bazı düşünceler. Fırat Üniversitesi Doğu Araştırmaları Dergisi, 4(2), 75-78.

Tekmen A. N., \& Takano, A. (2016). Japonca Dilbilgisi (3. Bask1). Ankara: Engin Yayınevi.

Tekmen A. N. (2010). Japon Şiiri Haiku ve Türk Edebiyatındaki yansıması. Ankara Üniversitesi Dil ve Tarih Coğrafya Fakültesi Türkoloji Dergisi, 17(1), 149-157. 